\title{
Entrepreneurial intentions and entrepreneurship education to University students in Portugal
}

\author{
María de la Cruz del Río-Rama ${ }^{1}$, Marta Peris-Ortiz ${ }^{2}$, José Álvarez-García ${ }^{3}$ and Carlos Rueda-Armengot ${ }^{2}$
}

*Correspondence:
mperis@doe.upv.es
2 Business Organisation
Department, Universitat
Politècnica de València,
Camino de Vera s/nº
42022 Valencia, Spain
Full list of author information
is available at the end of the
article

${ }^{*}$ Correspondence: article

\begin{abstract}
This article analyzes entrepreneurial intentions and motivations that encourage university students of Tourism to create their own company. Methodology is based on an empirical study, using a questionnaire adapted from a model of Veciana and Urbano (Actitudes de los estudiantes universitarios hacia la creación de empresas: un estudio empírico comparativo entre Catalunya y Puerto Rico. El emprendedor innovador y la creación de empresas de I + D + I, University of Valencia, pp 35-58, 2004), including the desirability and viability concepts. One hundred and sixty students answered the questionnaire from a total study population of 243 official Tourism degree students of the Superior Institute of Accounting and Management of Porto. This research finds out that the university students have a very positive perception about the desire to create their own company; a $90 \%$ of students express their desire to do it, and $83.5 \%$ express their intention. Moreover, a $57.5 \%$ think that within actual crisis it is more difficult to do than before it. This research lets us get an in-depth study of a student of Tourism degree, finding out his entrepreneurial attitudes. It can be the first step to wake up and encourage students' interest for starting up their own business.
\end{abstract}

Keywords: Attitudes for business, Obstacles for entrepreneurship, Potential entrepreneurs, Reasons for entrepreneurship, Students of tourism degree

\section{Background}

During current crisis and taking into account that different studies including Global Entrepreneurship Monitor demonstrate the ability of entrepreneurship to solve a lot of problems related to unemployment (Storey 1994 and White and Reynolds 1996) and to economic growth and to regional growth (Neck et al. 2003), it is very important to find out if University students have any intention to start up their own business, and the way the Universities can influence on students' attitudes and their knowledge about entrepreneurship with the aim to facilitate a tendency to create their own business in the future (Wang and Wong 2004). Regarding this Honjo (2004) claims that entrepreneurship of young people can be a possible way to contribute to economic development of countries. Urbano and Toledano (2008) say that nowadays "there is a widespread belief that economic growth, employment creation and innovative potential are linked to the ability of modern societies to create new enterprises".

() 2016 de la Cruz del Río-Rama et al. This article is distributed under the terms of the Creative Commons Attribution 4.0 International License (http://creativecommons.org/licenses/by/4.0/), which permits unrestricted use, distribution, and reproduction in any medium, provided you give appropriate credit to the original author(s) and the source, provide a link to the Creative Commons license, and indicate if changes were made. 
Entrepreneurship is very important in current society, mostly during the current crisis, and it could be a way to employ future Tourism graduated students, if we take into account the labour insertion data of 2014 of Tourism graduated students provided by the Ministry of Education of Spain that is of 52.75 \% (this data includes 51 Universities, being private 11 of them). Spanish data are used, because we do not have those of Portugal. High level of young people unemployment becomes a global problem as well; its estimated rate in countries belonging to the Organisation for Economic Co-operation and Development (OECD) is more than twice higher than the unemployment rate of adults. Portugal had a $34.5 \%$ unemployment rate of young people in May 2014 that is higher than the EU rate of a 23.6 \% (Eurostat 2014). This way the main goal of the European Commission is to cope with young people unemployment, so it is very important to analyze University functions: do Universities carry out any orientation programmes of job-placement for young people? Are entrepreneurial subjects important for education of young people?

If we take into account the fact that entrepreneurial future of a country will be a result of an appropriate combination of talent and knowledge, taking advantage of human capital in the best way possible, the role of Universities encouraging entrepreneurial spirit is essential. According to the GEM Portugal report (2012), education and academic training are very important for entrepreneurship. It is mandatory to strengthen entrepreneurial spirit and to reduce psychological and cultural barriers within the first phases of entrepreneurial process. Universities have to work with the aim to create potential entrepreneurs, very competitive young people with high educational level, having knowledge and tools to carry out their ideas and dreams. Haynie et al. (2009) consider that educational system must provide to the young people better education, filling a wide range of alternatives, identification of business opportunities and exploration.

There are a lot of studies speaking about entrepreneurial phenomenon, using different approaches and applying a wide range of theories according to the intended purpose, being considered this phenomenon an interdisciplinary and multidisciplinary field (Davidsson 1989). Thus, our starting point is to get to know models of entrepreneurial intentions, identified by Guerrero et al. (2008: 24): (1) Entrepreneurial Event Model (Shapero 1982), (2) Theory of Planned Behaviour (Ajzen 1991), (3) Entrepreneurial Attitude Orientation (Robinson et al. 1991), (4) Intentional Basic Model (Krueger and Carsrud 1993), (5) Entrepreneurial Potential Model (Krueger and Brazeal 1994), (6) Davidson model (Davidson 1995).

The studies carried out in this field are based on Shapero and Sokol (1982), Hyde (1989), Scherer et al. $(1989,1991)$ and Kolvereid's (1996) models which tried to identify factors encouraging entrepreneurial initiative, and which claim that social or environmental factors can explain entrepreneurial behavior. These factors are formal, such as laws, rules, or informal, such as ideas, beliefs, attitudes, social values, codes of conduct (Díaz et al. 2007). Entrepreneurship as a topic has been studied from different points of view: psychological approach studies personal factors, it means profile of a person; socio-demographic, psychological and situational factors (Fuentes et al. 2013: 42) of an entrepreneur (Fig. 1).

On the other hand, there is a sociocultural or institutional approach, studying factors of the society and the environment, which influence on the decision of business start-up. The Institutional Theory of North $(1990,2005)$ forms part of this approach, it explains that institutions are the rules of the game in a society (North 1993), created because the 


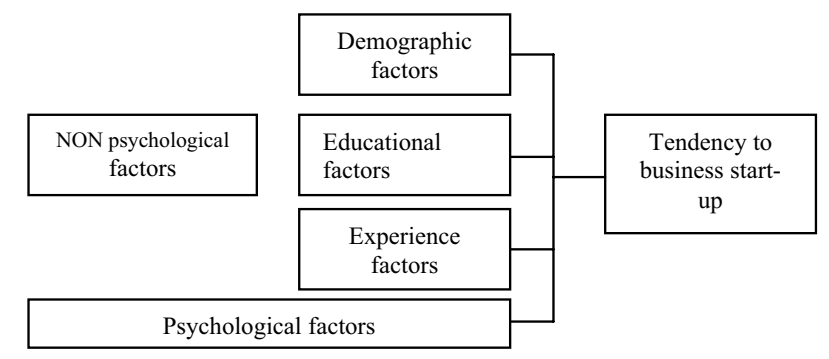

Fig. 1 Personal features and those of business creation. Shane (2003) and Hernangómez et al. (2005)

rules and standards regularizing human behavior and human relationship exist (Fuentes et al. 2013). There are different studies carried out taking into account this approach (Hyde 1989; North 1993; Aponte 2002; Díaz et al. 2007).

A model created by Krueger and Brazeal (1994) is very important from psycho-sociological point of view. On one hand, it tries to conceptualize, and, on the other hand, to prove the idea of "entrepreneurial potential". The model was developed using Shapero and Sokol's studies (1982) on the Azjen's Theory of Planned Behavior (1991). The study on entrepreneurship not only finds out a profile of an entrepreneur, and social or environmental factors, but also says that it is very important to make a decision to start up a business project. It offers a possibility to carry out a research in a new field; "personal intentions" (Fig. 2).

There are a lot of authors (Veciana et al. 2005; Díaz et al. 2007) that consider this model to be "the most appropriate approach for studying the intention as an explanatory factor for business start-up, due to its adjustment to the Institutional Theory." Fuentes et al. (2013: 47) focuses this analysis on informal institutions: attitudes and perceptions. As it can be seen in the Figs. 1, 2, entrepreneurial intention depends on two factors in the model of entrepreneurial potential: perceived desirability and perceived viability. The first concept is defined as a level of attraction for a person of an idea to start up a business project, and perceived viability is a level of self-confidence to start up a business project. "This way, Krueger and Brazeal's model (1994) establishes some relationship between perceptions of desirability and viability, credibility of being able to create a new enterprise, potential and "trigger incident" that makes somebody to make a decision (to create a new company)" (Fuentes et al. 2013: 49).

Between many factors, that favour entrepreneurial initiative university education can be distinguished, as it forms part of both psychological and sociocultural or institutional approaches. According to Fuentes et al. (2013: 49), Krueger and Brazeal think in their

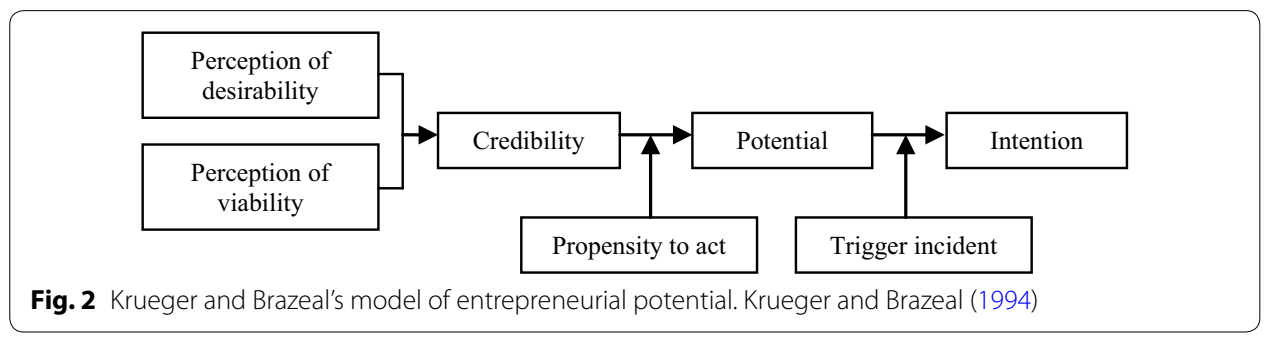


model that "potential can be provided by university education and by experience that can be achieved with practice". Thus, education, and specially university one, can be used as a way to increase and encourage entrepreneurial spirit of students. Similarly, Samad Aghayi (2008: 873) claims that "expanding entrepreneurial organizational culture is one of the most important factors that can play a vital role in changing people's tendency to self-occupation and entrepreneurship and prepares those people who have such culture for self-occupation labor market".

Summarizing, the impact of entrepreneurial education has been recognized as one of the most important factors that can help young people to understand and to encourage an attitude towards entrepreneurial initiative (Gorman et al. 1997; Kourilsky and Walstad 1998), and for this reason, the responsible politicians assume that an increase of the level of entrepreneurial spirit, that is, according to Miller et al. (2009), a very important part of economic situation, can be achieved through education (European Commission 2006).

In this regard, the studies carried out by Hernangomez et al. (2005); Dohse and Walter (2010); Lanero et al. (2011); De Jorge-Moreno et al. (2012); Gerba (2012); CabanaVillca et al. (2013); Yari et al. (2013); Bae et al. (2014), among others, are very interesting, because they study the level of significance of education and experience for a business start-up. Do Paço et al. (2011) made a review of recent studies that measure the impact of education on entrepreneurial spirit and entrepreneurial activity, and suggest that a positive relation between education and entrepreneurial spirit exists (Brice 2004; Hmieleski and Corbett 2006; Raposo et al. 2008a, b); entrepreneurial education based on development of competencies for entrepreneurship that includes knowledge, skills and abilities (Miller et al. 2009).

Although we have seen some studies in this regard (Genesca and Veciana Verges 1984; Veciana and Urbano 2004; Díaz et al. 2007; Fuentes et al. 2013), they analyze entrepreneurship in certain areas and take into account various degrees, i.e., studying the entrepreneurial profile of university students in general. However in our study, it seems important to determine whether the current curricular design of the degree in tourism (incipient studies in Portugal) within the framework of the European Higher Education Area, incorporates the tools and subjects needed to promote entrepreneurship among young people that are studying the degree or which studies must be adapted to comply with this objective in a country with a TEA rate (Total Early-Stage Entrepreneurial Activity rate) of $10 \%$ in 2012; 7-8 of early-stage entrepreneurs per 100 individuals in adulthood [Global Entrepreneurship Monitor (GEM Portugal 2012)].

This paper analyzes entrepreneurial attitude and motivations that make University tourism students create their own companies. As a partial objective, we would like to know their degree of intentionality of creating a company, to find out their motivations and the obstacles that, according to the students, stop them from the realization of an idea they have, to determine factors that can influence on their entrepreneurial intentions, to know the entrepreneur's image the students have, and, finally, to find out what the students can name as personal attributes a person has to have to become an entrepreneur. We would also like to know their point of view on Tourism degree's ability to encourage students to become entrepreneurs. 
Thus, this research lets us get an in-depth study of a student of Tourism degree, finding out his entrepreneurial attitudes. It can be the first step to wake up and encourage students' interest for starting up their own business.

\section{Results and discussion}

\section{Desirability, viability and intention to create a company}

The following table shows us the answers to three questions that let us know the valuation of entrepreneurial activity by the respondents. It can be seen that 144 students of 160 consider desirable to create their own company, but a $57.7 \%$ think that it is more difficult to do it now in comparison with the past. Instead of these difficulties, $85.5 \%$ of the students have a positive intention to create their own company (Table 1).

Comparing our study with other researches carried out in different countries of the world (Spain, Puerto Rico and Portugal), we can conclude that the answers of university students in Portugal are similar to the other students.

Table 1 Desirability, viability and intention to create a company

\begin{tabular}{|c|c|}
\hline Question & Answer \\
\hline $\begin{array}{l}\text { "Do you consider desirable to create your own com- } \\
\text { pany?" }\end{array}$ & $\%$ (144 responc \\
\hline \multicolumn{2}{|c|}{$\begin{array}{l}\text { In comparison with other studies: } \\
\text { Aponte et al. (2006): University students of Business Management and Engineering in Catalonia and Puerto Rico. } \\
\text { Yes, } 74 \% \text { Catalonia and } 92.2 \% \text { Puerto Rico. } \\
\text { Urbano (2006): Students of Business Studies of the Autonomous University of Catalonia. Yes, } 89.6 \% \text {. } \\
\text { Fuentes García (2007): Students of the University of Cordoba. Yes, } 75.6 \% \text {. } \\
\text { Díaz et al. (2007): University students of Beira Interior (Portugal) and university students of Extremadura (Spain) } \\
\text { different degrees. Yes, } 79.3 \% \text { Beira Interior and } 80.2 \% \text { Extremadura. } \\
\text { Fuentes et al. (2013): Students of the University of Cordoba. Yes, } 70.5 \% \text {. }\end{array}$} \\
\hline & Yes, it is easier, $42.5 \%$. No, it is more difficult, $57.5 \%$. \\
\hline $\begin{array}{l}\text { In comparison with other studies: } \\
\text { Aponte et al. (2006): University students of Business Man } \\
\text { Yes, it is easier, } 31.1 \% \text {; No, it is more difficult, } 66.1 \% \text { (C) } \\
53,5 \% \text { (Puerto Rico). } \\
\text { Fuentes García (2007): Students of the University of Corc } \\
\text { Díaz et al. (2007): University students of Beira Interior (Po } \\
\text { different degrees. Yes, it is easier, } 48 \% \text {; No, it is more di } \\
\text { more difficult, 43.4 \% (Extremadura). } \\
\text { Fuentes et al. (2013): Students of the University of Cordo }\end{array}$ & $\begin{array}{l}\text { ement and Engineering in Catalonia and Puerto Rico. } \\
\text { onia); Yes, it is easier, } 44.4 \% \text {; No, it is more difficult, } \\
\text { a. Yes, it is easier, } 46.3 \% \text {; No, it is more difficult, } 53.7 \% \\
\text { gal) and university students of Extremadura (Spain) } \\
\text { ult, } 51 \% \text { (Beira Interior); Yes, it is easier, } 55.4 \% \text {; No, it is } \\
\text { Yes, it is easier, } 14.2 \% \text {; No, it is more difficult, } 85.3 \%\end{array}$ \\
\hline Intention to create your own company & $\begin{array}{l}83.5 \% \text { have a positive intention to create a company } \\
16.5 \% \text { have never seriously thought about creating of } \\
\text { their own company }\end{array}$ \\
\hline
\end{tabular}

In comparison with other studies:

Aponte et al. (2006): University students of Business Management and Engineering in Catalonia and Puerto Rico. A $62.1 \%$ have a positive intention to create a company; a $26.8 \%$ have never seriously thought about creating of their own company (Catalonia). A 85,1\% have a positive intention to create a company; a $10.8 \%$ have never seriously thought about creating of their own company (Puerto Rico).

Urbano (2006): Students of Business Studies of the Autonomous University of Catalonia. A $68.2 \%$ have a positive intention to create a company; a $27.4 \%$ have never seriously thought about creating of their own company

Fuentes García (2007): Students of the University of Cordoba. A $73.3 \%$ have a positive intention to create a company; a $22.6 \%$ have never seriously thought about creating of their own company

Díaz et al. (2007): University students of Beira Interior (Portugal) and university students of Extremadura (Spain) different degrees. A $66.7 \%$ have a positive intention to create a company; a $32.1 \%$ have never seriously thought about creating of their own company (Beira Interior). A $74.1 \%$ have a positive intention to create a company; a $21.6 \%$ have never seriously thought about creating of their own company (Extremadura).

Fuentes et al. (2013): Students of the University of Cordoba. A $66.7 \%$ have a positive intention to create a company; a $27 \%$ have never seriously thought about creating of their own company. 
The questionnaire also includes a question that pretends to analyze university students' perception of their entrepreneurial capability. A $29 \%$ of the respondents answered 7 to the question: "In a scale from 1 to 10, how entrepreneurial, dynamic, innovative you are?" A $60.7 \%$ of the respondents placed themselves between 6 and 8, and there is a $3.8 \%$ who consider themselves very entrepreneurial (10).

\section{Reasons and obstacles for entrepreneurship}

The students were asked about their perception of reasons that could encourage them to create their own company. In Table 2 we can see three most important ones: possibility to develop my own ideas, to create something by my own (to achieve personal patrimony), searching of new challenges. On the other hand, the less relevant reasons are: family tradition, dissatisfaction with a previous job, and to get prestige, status and reputation. As main obstacles, the students named lack of starting capital, difficulties in obtaining financing, and high risk.

Obtained results are similar to those got by other researches, as Fuentes et al. (2013) that highlighted as main reasons: possibility to develop my own ideas, personal independence, and to create something by myself. As for the main factors complicating in general business start-up in Fuentes's study, they are similar to those named by Portuguese students: lack of capital and economic abilities, financing, a high number of legal requirements, and lack of public assistance.

\section{Personal characteristics and important factors an entrepreneur has to have}

As for personal characteristics, it means, qualities related to entrepreneurship, the students were asked to mark their level of agreement and disagreement with the statements of Table 3. The most important characteristics for them are: I consider that it is very important to be a self-employed worker, I assume the responsibility of my decisions, I

Table 2 Reasons and obstacles for business start-up

\begin{tabular}{|c|c|c|c|}
\hline \multicolumn{2}{|l|}{ Reasons } & \multicolumn{2}{|l|}{ Obstacles } \\
\hline Possibility to develop my own ideas & 5.9438 & Lack of start-up capital & 6.1938 \\
\hline $\begin{array}{l}\text { To create something by my own } \\
\text { (to achieve personal patrimony) }\end{array}$ & 5.9063 & Difficulty in obtaining financing & 5.9750 \\
\hline Searching of new challenges & 5.7125 & Too high risk & 5.7000 \\
\hline To carry out a personal dream & 5.5438 & Unfavourable economic climate & 5.2875 \\
\hline To invest in personal patrimony & 5.5063 & Tax burden & 5.1313 \\
\hline Economic independence & 5.4375 & Fear to fail & 4.9688 \\
\hline $\begin{array}{l}\text { To get a fair compensation in relation } \\
\text { with my work }\end{array}$ & 5.3688 & $\begin{array}{l}\text { To control annual income in relation } \\
\text { with the profit }\end{array}$ & 4.9000 \\
\hline $\begin{array}{l}\text { To earn more money in comparison } \\
\text { with the money earned as a employee }\end{array}$ & 5.3250 & Good job expectations as an employee & 4.8688 \\
\hline $\begin{array}{l}\text { Personal independence (freedom of decision } \\
\text { and action) }\end{array}$ & 5.2750 & $\begin{array}{l}\text { Lack of business knowledge and } \\
\text { knowledge of potential clients }\end{array}$ & 4.7563 \\
\hline To run a company & 5.2250 & Lack of guaranteed minimum wage & 4.5375 \\
\hline Impossibility o difficulty to find an appropriate job & 4.8563 & High responsibility & 4.3250 \\
\hline To get prestige, status or reputation & 4.7063 & Lack of innovative ideas & 4.0563 \\
\hline Dissatisfaction with a previous job & 4.0938 & Lack of family and friends' support & 3.4125 \\
\hline Family tradition & 3.2625 & Have to work a lot of hours & 3.3188 \\
\hline
\end{tabular}


Table 3 Personal characteristics and important factors

\begin{tabular}{llll}
\hline Personal characteristics & & Important factors \\
\hline $\begin{array}{l}\text { I consider that it is very important to be a } \\
\text { self-employed worker }\end{array}$ & 5.7563 & To know how to satisfy clients'needs & 6.1938 \\
I assume the responsibility of my decisions & 5.7000 & To know the market & 6.1688 \\
I work so many hours I need for working well & 5.6688 & To have entrepreneurial vision & 6.0750 \\
I get on easily with other people & 5.4313 & To be independent and self-confident & 6.0375 \\
To face new projects encourage me & 5.3563 & & \\
I get used easily to the changes & 5.3313 & To be able to set up goals/challenges & 6.0188 \\
I am a very dedicated person starting a new project & 5.3313 & To have quality and to be efficient & 5.9375 \\
I trust my personal and professional abilities and & 5.2875 & To be organized & 5.7938 \\
$\quad$ possibilities & & & \\
I am worried about a possibility of failing & 5.2188 & Good financial system & 5.7000 \\
I am creative and innovative resolving problems & 5.1250 & To be able to manage human resources & 5.6875 \\
I face obstacles in an optimistic and cheerful way & 4.9813 & To have a lot of contacts in the area & 5.6813 \\
I have enough leadership abilities to become & 4.9750 & To have own experience in business & 5.3750 \\
an entrepreneur & & & \\
I can make decisions in difficult situations & 4.9250 & To be a relative of an entrepreneur & 3.2313 \\
I can work many hours & 4.8500 & & \\
I have mental abilities to become an entrepreneur & 4.8550 & & \\
\hline
\end{tabular}

work so many hours I need for working well. As for important factors for those who want to create their company, the students marked: to know how to satisfy clients' needs, to know the market and to have entrepreneurial vision.

\section{Entrepreneur's image according to the students}

University students' perception of an entrepreneur's image in our modern society was analyzed. 14 characteristics had to be valued from 1 (totally disagree) to 7 (totally agree). As the most important characteristics, the students named: to be an active person (5.6563), to have an ability to organize and to work (5.5688), to have an innovative mind (5.4625), to have wide financial and managing abilities (5.3250). The less valued characteristics were: to be fair with the society (4.35), and to be a honest person (4.5375).

\section{University education for entrepreneurship}

In this last part of the questionnaire, we wanted to know students' vision of the ability of Tourism degree they are studying to encourage their entrepreneurial spirit. A $96.3 \%$ of the students think that entrepreneurial subjects are very important, and a $97.5 \%$ claim that the function to encourage entrepreneurship belongs to the university through education, developing in a student basic characteristics, important for an entrepreneur.

The students think that their actual and future education doesn't give them enough knowledge and tools to start their own business. They answered the following questions in a scale from 1 to 7: 3.7187 "My actual studies give me essential knowledge and tools to create my own company", 4.1270 "I feel that I don't have all necessary business knowledge to create my own company", 6.0475 "Universities would have to support company creation by students", 5.5063 "I would like to have in my university more subjects about entrepreneurship". 


\section{Conclusions}

The originality and value of the research consisted in determining if the curricular design of the degree in tourism adapted to the guidelines of the new European Higher Education Area (EHEA) have been designed considering the necessity to promote and support entrepreneurship, especially in the current context where the unemployment rate is very high among young people, which can alleviate this situation.

This research finds out that students of Tourism degree by the Superior Institute of Accounting and Management of Porto (Portugal) have a very positive perception about the desire to create their own company; a $90 \%$ of students have this desire and a $83.5 \%$ this intention. Moreover, a $57.5 \%$ think that within actual crisis it is more difficult to do than before it. Speaking about the reasons that could make them to create their own company, we can highlight 3 of them: a possibility to develop my own ideas, to create something by my own, and to search new challenges. As main obstacles, we can emphasize lack of starting capital, difficulties in obtaining financing, and high risk.

As for education received in the University, they think that entrepreneurial subjects are very important, and that Universities have to encourage entrepreneurship. However, they think that knowledge and tools they receive are not enough to start their own business.

These results show that there is a very high entrepreneurial spirit (desirability and intention) amongst the students of Tourism degree in Portugal. However, the students claim that their studies should have more subjects that could provide them basic and necessary tools to become an entrepreneur, the subjects that would help them to develop some abilities that would help them to achieve success being entrepreneurs, and abilities and skills that could help them not only to develop and idea, but also to create a company.

The generation of the entrepreneurial spirit among university students should be supported by the formation in university centers, however at the same time, "governments need to design focused policies giving higher priority to nurturing local entrepreneurs, promoting successful entrepreneurial role models and removing bureaucratic impediments to start-ups and business-like initiatives" (Trequattrini et al. 2015: 1).

The study results allow the academic managers to deeply express what they feel and think in order to grade students of Tourism curricular design focused on entrepreneurship and implement the actions required to adapt to the needs of their students and achieve their satisfaction and more importantly, meet the current needs of society in times of crisis like the present.

Limitations of this study are caused by the fact that study's population and the sample come from only one University, and that all questioned students study Tourism degree, that's why we cannot extrapolate the results. As possible future research, we can offer to repeat this research in other universities, but always with Tourism degree students, because we believe that it is important to analyze their tendency to start up their own business and verify whether sociocultural characteristics of countries affect the entrepreneurial intention of its youth and to what extent.

\section{Methods}

This research uses a wide sample of the University students of Tourism degree by the Superior Institute of Accounting and Management of Porto (Portugal) that is an important source of potential entrepreneurs (Veciana 1989). 
The questionnaire was answered by 160 students from a total study population of 243 official Tourism degree students. It means $\pm 4.62 \%$ sampling error with a confidence level of $95 \% \mathrm{Z}=1.96 \mathrm{p}=\mathrm{q}=0,5$. The questionnaire was answered from April until May 2014, and the data was analyzed with SPSS 17 and Excel. Descriptive univariate analysis was used as a statistical technique (frequencies and percentages).

Regarding the sample description, if we take into account the sex of survey respondents, women represent a $60.6 \%$, and men represent a $39.4 \%$ (in Tourism studies the number of female students are higher than the number of male ones), being urban their place of residence in a $81.2 \%$ of cases. Regarding their age, a $65.6 \%$ (105 respondents) are from 20 to 25 years old, and a $28.1 \%$ is less than 20 years old. Barely $5 \%$ (8 respondents) are from 26 to 35 years old. A $54.4 \%$ of students have at least one entrepreneur in their families (a $20 \%$ answered that it was their father, and a $30 \%$-other person: uncle, cousin...).

The methodological approach used in this research is the Institutional Economic Theory of Douglas North $(1990,2005)$. This theory addresses the institutional analysis of business creation. Methodology is based on an empirical study, using a questionnaire adapted from a Veciana and Urbano model (2004) of attitudes for business start-up that has been already used in other universities (Veciana et al. 2005; Díaz et al. 2007; Raposo et al. 2008), and including our own questions. This questionnaire is an extended version of that one used in Genesca and Veciana's research (1984), adding some questions using a Shapero and Shokol's model (1982) and Krueger and Brazeal's model (1994), studying both of them business start-up intentions, concepts of desirability and viability, because both of them claim that business start-up intention comes from both perceptions.

In the questionnaire about attitudes for business start-up, university students were asked about desirability and viability of creating their own company, the reasons for making this decision, and the obstacles they think they can face. We also tried to figure out through offered statements which personal characteristics they think an entrepreneur has to have, which external factors could make easier this process, and the image of a modern entrepreneur they have. The last part of the questionnaire includes some questions that help us to analyze if they receive in Tourism studies in the university is considered by them appropriate enough to encourage entrepreneurial spirit. All these questions had to be answered taking into account Liker scale of 7 points, where 1 means totally disagree, and 7 means totally agree.

Authors' contributions

All authors contributed equally even if their names are not in alphabetical order. All authors read and approved the final manuscript.

\section{Author details}

Business Organisation and Marketing Department, University of Vigo, Facultad de Ciencias Empresariales y Turismo, As Lagoas s/n, 32004 Ourense, Spain. ${ }^{2}$ Business Organisation Department, Universitat Politècnica de València, Camino de Vera s/nº, 42022 Valencia, Spain. ${ }^{3}$ Finacial and Acounting Economy Department, University of Extremadura, Avenida de la Universidad, n 47, 10071 Cáceres, Spain.

\section{Competing interests}

The authors declare that they have no competing interests.

Received: 24 November 2015 Accepted: 14 April 2016

Published online: 20 May 2016 


\section{References}

Ajzen I (1991) The theory of plannes behavior. Organ Behav Hum Decis Process 50:179-211

Aponte M (2002) Factores condicionantes de la creación de empresas en Puerto Rico: un enfoque institucional. Doctoral dissertation, Autonomous University of Barcelona

Aponte M, Urbano D, Veciana JM (2006) Actitudes hacia la creación de empresas: un estudio comparativo entre Catalunya y Puerto Rico. Centro de Investigaciones Comerciales e Iniciativas Académicas de la Facultad de Administración de Empresas. Forum Empresarial 11(2):52-75

Bae TJ, Qian S, Miao C, Fiet JO (2014) The relationship between entrepreneurship education and entrepreneurial intentions: a meta-analytic review. Entrep Theory Pract 38(2):217-254

Brice J (2004) The role of personality dimensions on the formation of entrepreneurial intentions. USASBE Small Business Advancement National Center. University of Central Arkansas, USA

Cabana-Villca R, Cortes-Castillo I, Plaza-Pasten D, Castillo-Vergara M, Alvarez-Marin A (2013) Análisis de las capacidades emprendedoras potenciales y efectivas en alumnos de centros de educación superior. J Technol Manag Innov 8(1):65-75

Davidsson P (1989) Continued entrepreneurship and small firm business. Stockholm School of Economics, Stockholm

Davidsson P (1995) Culture, structure and regional levels of entrepreneurship. Entrep Reg Dev 7(1):41-62

De Jorge-Moreno J, Castillo LL, Triguero MS (2012) The effect of business and economics education programs on students'entrepreneurial intention. Eur J Train Dev 36(4):409-425

Díaz JC, Hernández RM, Barata ML (2007) Estudiantes universitarios y creación de empresas. Un análisis comparativo entre España y Portugal. In Ayala, J.C. (coord.) Conocimiento, innovación y emprendedores: camino al futuro. Grupo FEDRA, Madrid

Do Paço AMF, Ferreira JM, Raposo M, Rodrigues RG, Dinis A (2011) Behaviours and entrepreneurial intention: empirical findings about secondary students. J Int Entrep 9(1):20-38

Dohse D, Walter SG (2010) The role of entrepreneurship education and regional context in forming entrepreneurial intentions (No. 2010, 18). Document de treball de l'IEB

European Commission (2006). Entrepreneurship education in Europe: Fostering entrepreneurial mindsets through education and learning, Final Proceedings of the Conference on Entrepreneurship Education in Os/o

Eurostat (2014) Informes sobre el empleo en la Unión Europea. Available in: http://europa.eu/publications/statistics/ index_es.htm

Fuentes F, Saco F, Rodríguez P (2013) Estudio sobre el perfil emprendedor en el alumnado universitario de Córdoba. UCO Consejo Social de la Universidad de Córdoba, III Edición, Córdoba, pp 1-180

Fuentes García FJ (2007) Análisis del Perfil Emprendedor del alumnado universitario y preuniversitario de Córdoba. Consejo Social Universidad de Córdoba, pp 1-105

Genesca Garrigosa E, Veciana Verges JM (1984) Actitudes hacia la creación de empresas. Información Comercial Española 611:147-155

Gerba DT (2012) Impact of entrepreneurship education on entrepreneurial intentions of business and engineering students in Ethiopia. Afr J Econ Manag Stud 3(2):258-277

Gorman G, Hanlon D, King W (1997) Some research perspectives on entrepreneurship education and education for small business management: a ten-year literature review. Int Small Bus J 15(3):56-77

Guerrero M, Rialp J, Urbano D (2008) The impact of desirability and feasibility on entrepreneurial intentions: a structural equation model. Int Entrep Manag J 4(1):35-50

Haynie JM, Shepherd DA, McMullen JS (2009) An opportunity for me? The role of resources in opportunity evaluation decisions. J Manage Stud 46(3):337-361

Hernangomez J, Martín N, Rodriquez Al, Saboia F (2005) El emprendedor nace o se hace? Un análisis de los determinantes del espíritu emprendedor. XVI Spanish-Portuguese Meeting of Scientic Management. Sevilla:33-44

Hmieleski KM, Corbett AC (2006) Proclivity for improvisation as a predictor of entrepreneurial intentions. J Small Bus. Manage 44(1):45-63

Honjo Y (2004) Growth of new start-up firms: evidence from the Japanese manufacturing industry. Appl Econ Lett $11(1): 21-32$

Hyde GC (1989) The relationship between policy and research. In Rosa, P.; Birley, S. Cannon, T. and O'Neill, K. The Role and Contribution of Small Business Research, Chap. 3:55-77, Institute Report

Kolvereid L (1996) Prediction of employment status choice intentions. Entrep Theory Pract 21(1):47-57

Kourilsky ML, Walstad WB (1998) Entrepreneurship and female youth: knowledge, attitude, gender differences, and educational practices. J Bus Ventur 13(1):77-88

Krueger N, Brazeal D (1994) Entrepreneurial Potencial and Potencial Entrepreneurs. Entrep Theory Pract 18(3):91-104

Krueger NF, Carsrud AL (1993) Entrepreneurial intentions: applying the theory of planned behaviour. Entrep Reg Dev 5(4):315-330

Lanero A, Vázquez JL, Gutiérrez P, García MP (2011) The impact of entrepreneurship education in European universities: an intention-based approach analyzed in the Spanish area. Int Rev Public Nonprofit Marketin 8(2):111-130

Miller BK, Bell JD, Palmer M, González A (2009) Predictors of entrepreneurial intentions: a quasi-experiment comparing students enrolled in introductory management and entrepreneurship classes. J Bus Entrep 21(2):39-62

Neck HM, Zacharakis AL, Bygrave WD, Reynolds PD (2003) Global entrepreneurship monitor: 2002 executive report. Babson College, Babson, MA

North DC (1990) Institutions, Institutional Change and Economic Performance. Cambridge University Press, Cambridge (UK)

North D (1993) Instituciones, cambio institucional y desempeño económico. Fondo de Cultura Económica, México North DC (2005) Understanding the Process of Economic Change. Academic Foundation. University Press, Princenton GEM Portugal (2012) Estudo sobre o Empreendedorismo. Global Entrepreneruship Monitor (GEM). Instituto Universitário de Lisboa (ISCTEIUL) http://web.spi.pt/GEMportugal2012/files/GEM_PORTUGAL_2012.pdf

Raposo M, do Paço A, Ferreira J (2008a) Entrepreneur's profile: a taxonomy of attribu tes and motivations of university students. J Small Bus Enterp Dev 15(2):405-420 
Raposo MLB, Ferreira JJM, do Paço AMF, Rodrigues RJG (2008b) Propensity to firm creation: empirical research using structural equations. Int Entrep Manag J 4(4):485-504

Robinson PB, Stimpson DV, Huefner JC, Hunt HK (1991) An attitude approach to the prediction of entrepreneurship. Entrep Theory Pract 15(4):13-31

Samad Aghayi J (2008) Entrepreneurship organization. Public Administration Training Center Publications, Tehran

Scherer RF, Adams JS, Carley S, Wiebe FA (1989) Role model performance effects on development of entrepreneurial career preference. Entrep Theory and Pract, spring:53-71

Scherer RF, Brodzinski JD, Wiebe F (1991) Examining the relationship between personality and entrepreneurial career preference. Entrep Reg Dev 3(2):195-206

Shane S (2003) A General Theory of Enttrepreneurship- The Individual Oportunity Nexus. Edward Elgar Editores

Shapero A (1982) Social dimensions of entrepreneurship. In: Kent CA et al (eds) The encyclopedia of entrepreneurship. Prentice-Hall, Englewood Cliffs, pp 72-89

Shapero A, Sokol L (1982) The social dimensions of entrepreneurship.Encyclopedia of Entrepreneurship:72-90

Storey DJ (1994) Employment. In Storey, D.J. Understanding the small business sector. Capítulo 6, pp. 160-203. London: Routledge

Toledano N, Urbano D (2008) Promoting entrepreneurial mindsets at universities: a case study in the South of Spain. Eur J Int Manag 2(4):382-399

Trequattrini R, Lombardi R, Lardo A, Cuozzo B (2015). The Impact of Entrepreneurial Universities on Regional Growth: a Local Intellectual Capital Perspective. Journal of the Knowledge Economy, 1-13

Urbano D (2006) La creación de empresas en Catalunya. Organismos de apoyo y actitudes hacia la actividad emprendedora, Ed. Generalitat de Catalunya-CIDEM, Barcelona

Urbano D, Toledano N (2008) The systems of university education and their influence on the students' attitudes in the business world: a multiple case study. Oikos 25:87-103

Veciana JM (1989) Características del empresario en España. Papeles de Economía Española 39:19-36

Veciana JM, Urbano D (2004) Actitudes de los estudiantes universitarios hacia la creación de empresas: un estudio empírico comparativo entre Catalunya y Puerto Rico. El emprendedor innovador y la creación de empresas de I + D + I, University of Valencia, pp 35-58

Veciana JM, Aponte M, Urbano D (2005) University student's attitudes towards entrepreneurship: a two countries comparison. Int Entrep Manag J 1:165-182

Wang CK, Wong PK (2004) Entrepreneurial interest of university students in Singapore. Technovation 24(2):163-172 White SB, Reynolds PD (1996) Government programs and high growth new firms. Frontiers of Entrepreneurship Research. Center for Entrepreneurial Studies Babson College. Wellesley, MA.: 621-635

Yari A, Toulabi Z, Pourashraf Y (2013) Designing propensity to entrepreneurship paradigm in llam universities (structural equation model approach). J Novel Appl Sci 2:872-880

\section{Submit your manuscript to a SpringerOpen ${ }^{\circ}$ journal and benefit from:}

- Convenient online submission

Rigorous peer review

- Immediate publication on acceptance

Open access: articles freely available online

- High visibility within the field

- Retaining the copyright to your article

Submit your next manuscript at $>$ springeropen.com 